
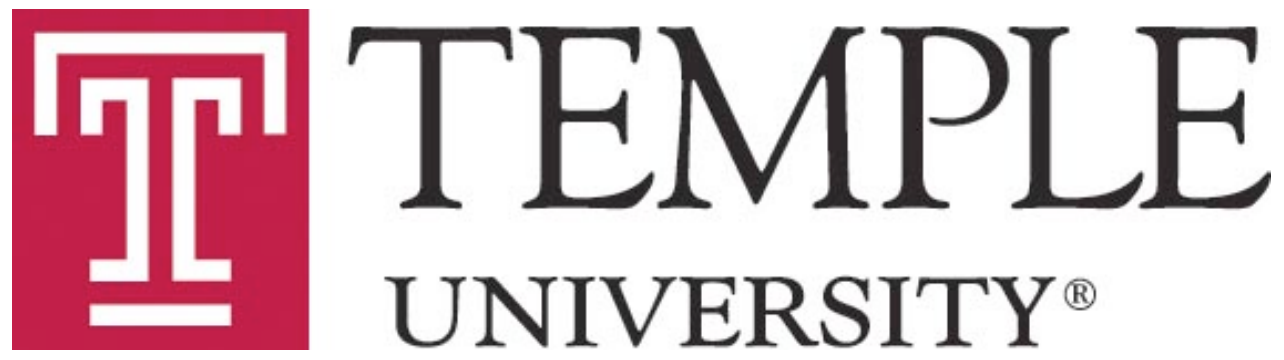

\title{
Economic conditions at school-leaving and self-employment
}

Keshar Mani Ghimire

Department of Economics

Temple University

Johanna Catherine Maclean

Department of Economics

Temple University

Department of Economics

DETU Working Paper 15-12

September 2015

1301 Cecil B. Moore Avenue, Philadelphia, PA 19122

http://www.cla.temple.edu/economics/faculty/detu-working-paper-series/ 


\title{
Economic conditions at school-leaving and self-employment
}

\author{
Keshar Mani Ghimire ${ }^{a}$ Johanna Catherine Maclean ${ }^{\text {b* }}$ \\ a PhD Candidate, Department of Economics, Temple University, USA \\ Email: keshar.ghimire@temple.edu \\ ${ }^{\mathrm{b}}$ Associate Professor, Department of Economics, Temple University, USA \\ Email: catherine.maclean@temple.edu \\ * Corresponding Author \\ September, 2015
}

\begin{abstract}
In this study we use the National Longitudinal Survey of Youth 1979 to estimate the impact of economic conditions at school-leaving on self-employment at various points across the lifecourse. We find no evidence that the economic conditions at school-leaving affect self-employment.
\end{abstract}

JEL Codes: J21; J24

Keywords: Self-employment; Macroeconomic fluctuations; School-leaving 


\section{Introduction}

Individuals who leave school during economic downturns have persistently lower wages, have less access to fringe benefits, and work in less prestigious jobs (Kahn, 2010; Maclean, 2014; Oreopoulos, Wachter, \& Heisz, 2012). For example, Kahn (2010) shows that a one percentage point increase in the schoolleaving state unemployment rate reduces wages by $2.5 \%$ up to 15 years after school-leaving among white, male college graduates. Moreover, effects are not homogenous across worker types (Altonji, Kahn, \& Speer, 2014; Genda, Kondo, \& Ohta, 2010; Hershbein, 2012; Kondo, 2007).

One in nine American workers is self-employed (Hipple, 2010) and selfemployment is an important component of the United States (US) economy (Haltiwanger, Jarmin, \& Miranda, 2013). Thus, understanding factors that predict who chooses to enter self-employment, and why, is important for understanding US labor markets. Because past labor market experiences are important determinants of self-employment (Evans \& Leighton, 1989), it is plausible that economic conditions at school-leaving affect self-employment choices.

In this paper we study the impact of economic conditions at school-leaving on self-employment at various points across the lifecourse using the National Longitudinal Survey of Youth 1979 (NLSY79). We find no evidence that economic conditions at school-leaving are related to self-employment outcomes. Our results are in contrast to the finding of Yu, Orazem, and Jolly (2014) which implies that economic conditions at school-leaving affect selfemployment propensities up to 11 years after graduation.

\section{Background}

The impact of the economic conditions at school-leaving on the propensity of self-employment is ambiguous. On one hand, individuals leaving school during downturns may find it harder to secure a high quality job - for example, in terms of wages, prestige, and access to non-wage benefits - and may be more likely to start a business as an alternative to employment for wages (Fairlie, 2013). On the other hand, greater availability of credit and increased willingness to take risks during economic expansions (Rampini, 2004) may allow individuals who leave school in an upturn to enter self-employment. Moreover, individuals entering the labor market during expansions are more likely to begin their career in a high quality job (Kahn, 2010), thus have more ability to accumulate savings required to start a business in the long run. 
The empirical evidence on the issue is limited to one study based on a survey of college graduates of Iowa State University (Yu et al., 2014). The authors conclude that graduating in downturns reduces the probability of starting a business for up to 11 years after school-leaving. Although this study is important, it has limitations. First, by relying on graduates of one university the authors cannot control for area fixed effects such as the level of banking system support available for entrepreneurs. Failure to do so can lead to omitted variable bias. Second, the findings for college graduates may not generalize to other worker types. We provide new evidence drawn from a nationally representative sample, specifically designed to study labor market transitions, that covers the full spectrum of education levels. ${ }^{1}$

\section{Data, Variables, and Methods}

We draw a balanced panel of 5,876 individuals from the NLSY79. Although we focus on the balanced panel to avoid composition changes driving effects, the results are robust to using the unbalanced panel.

We consider five outcome variables each of which is a binary indicator for whether an individual is self-employed at 5, 10, 15, 20, and 25 years after school-leaving. ${ }^{2}, 325$ years after school-leaving is the most recent period we can observe outcomes for members of the cohort. The key explanatory variable is the economic conditions at school-leaving. We use the annual seasonally adjusted school-leaving state unemployment rate as proxy for the economic conditions. We control for a large number of pre-determined individual characteristics, including individual ability measured by the age-standardized Armed Force Qualifying Test (AFQT) scores (Kahn, 2010).

The baseline empirical model takes the form:

$$
S E_{i s t y}=\alpha_{0}+\alpha_{1} U_{s t}+\alpha_{2}^{\prime} X_{i}+\alpha_{3}^{\prime} S_{s}+\alpha_{4}^{\prime} D_{t}+\epsilon_{i s t y}
$$

\footnotetext{
${ }^{1}$ Our dependent variable, explained in the following section, differs slightly from that considered by Yu et al. (2014) in that it measures the self-employment propensities at various points across the lifecourse. Nevertheless, the variables plausibly measure the same concept.

${ }^{2}$ The universe of jobs for classifying respondents as self-employed in NLSY79 has evolved over the years. Details on exact changes are available at https://www.nlsinfo.org/content/cohorts/nlsy79/topical-guide/ employment/class-worker Because the NLSY79 became biennial in 1994 and there is attrition, we impute these indicators for some individuals. Details are available on request.

${ }^{3}$ School-leaving state and year are located using state geocodes and retrospective questions on school-leaving. See Maclean (2014) for details.
} 
where $S E_{\text {isty }}$ indicates if an individual $i$ in school-leaving state $s$ and schoolleaving year $t$ is self-employed $5,10,15,20$, or 25 years after school-leaving, $U_{s t}$ is the unemployment rate in school-leaving state s and school-leaving year t, $X_{i}$ is a vector of individual characteristics, $S_{s}$ is a vector of school-leaving state fixed effects, $D_{t}$ is a vector of school-leaving year fixed effects, $\epsilon_{i s t y}$ is the random error term, and the $\alpha$ s are the parameter vectors.

$\alpha_{1}$ captures the impact of the economic conditions at school leaving on selfemployment propensity. Since the self-employment rates significantly differ by sex (Hipple, 2010), we estimate separate regressions for men and women. We fit linear probability models (LPM) and adjust the standard errors for clustering around the school-leaving state.

Identification of Equation (1) hinges on the assumption that the state unemployment rate at school-leaving is uncorrelated with the error term after we condition on individual characteristics and fixed effects. However, if individuals engage in behaviours to avoid leaving school in downturn -for example obtaining additional schooling -this assumption will be violated (Maclean, 2014; Oreopoulos et al., 2012). Therefore, we utilize two stage least squares (TSLS). We select instruments that have been utilized in previous studies of the persistent effects of leaving school in an economic downturn (Kahn, 2010) and are based on birth year, state of residence at age 14, and early educational expectations. We use this information to predict the year and state in which we expect respondents to leave school ('expected school-leaving').

\section{Results}

Summary statistics are reported in Table 1.

Results from the first-stage regressions presented in Table 2 suggest our instruments are powerful.

Table 3 presents selected estimates from the LPM and TSLS models. We find no statistically significant evidence that the school-leaving state unemployment rate affects the probability of self-employment. Of 20 models we estimate, only one coefficient is statistically different from zero, only at the $10 \%$ level. We suspect that the single significant coefficient is merely by chance.

In unreported regressions, we estimate the impact of school-leaving state unemployment rate on self-employment propensity conditional on being employed and we examine heterogeneity by worker type (race, skill). The results are not appreciably different from those presented here. In particular, the findings are comparable among college graduates. 
Table 1

Summary Statistics

\begin{tabular}{lcc}
\hline \hline Sample: & Men & Women \\
\hline Self-employment outcomes & & \\
\hline Self-employed 5 years after school-leaving & 0.0490 & 0.0360 \\
Self-employed 10 years after school-leaving & 0.0826 & 0.0756 \\
Self-employed 15 years after school-leaving & 0.104 & 0.0804 \\
Self-employed 20 years after school-leaving & 0.119 & 0.0768 \\
Self-employed 25 years after school-leaving & 0.150 & 0.0801 \\
\hline School-leaving variables & & \\
\hline School-leaving state unemployment rate & 7.497 & 7.449 \\
Expected school-leaving state unemployment rate & 7.573 & 7.579 \\
\hline Demographics & & \\
\hline White & 0.819 & 0.811 \\
Black & 0.124 & 0.137 \\
Hispanic & 0.0572 & 0.0521 \\
Age-adjusted AFQT & 0.261 & 0.249 \\
Live with both biological parents at age 14 & 0.775 & 0.760 \\
Live in rural area at age 14 & 0.225 & 0.228 \\
Speak foreign language in home at age 14 & 0.127 & 0.121 \\
Library card in home at age 14 & 0.753 & 0.790 \\
Magazines in home at age 14 & 0.701 & 0.698 \\
Newspapers in home at age 14 & 0.859 & 0.844 \\
\hline Observations & 2,968 & 2,908 \\
\hline Notes: & & \\
\hline & & \\
\hline
\end{tabular}

Notes: NLSY79 sample weights applied. 
Table 2

First stage regressions

\begin{tabular}{lcc}
\hline \hline & Men & Women \\
\hline Sample mean school-leaving state unemployment rate & 7.497 & 7.449 \\
\hline Expected school-leaving state unemployment rate & $\begin{array}{c}0.336^{* * *} \\
(0.044)\end{array}$ & $\begin{array}{c}0.341^{* * *} \\
(0.058)\end{array}$ \\
\hline F-statistic (p-value) & $\begin{array}{c}58.76 \\
(0.058)\end{array}$ & $\begin{array}{c}35.10 \\
(0.058)\end{array}$ \\
\hline Observations & 2,968 & 2,908
\end{tabular}

Notes: All models control for demographics, and school-leaving state, and year fixed effects. NLSY79 sample weights applied. Standard errors reported in parentheses and clustered around the school-leaving state. ${ }^{*} \mathrm{p}<.10 .{ }^{* *} \mathrm{p}<.05$. $* * * \mathrm{p}$ $<.01$.

Table 3

Effect of the state unemployment rate at school-leaving on the probability of self-employment across the lifecourse

\begin{tabular}{lccccc}
\hline \hline Self-employment: & $\begin{array}{c}\text { 5 years } \\
\text { after } \\
\text { school- } \\
\text { leaving }\end{array}$ & $\begin{array}{c}\text { 10 years } \\
\text { after } \\
\text { school- } \\
\text { leaving }\end{array}$ & $\begin{array}{c}\text { 15 years } \\
\text { after } \\
\text { school- } \\
\text { leaving }\end{array}$ & $\begin{array}{c}\text { 20 years } \\
\text { after } \\
\text { school- } \\
\text { leaving }\end{array}$ & $\begin{array}{c}\text { 25 years } \\
\text { after } \\
\text { school- } \\
\text { leaving }\end{array}$ \\
\hline Men & & & & & \\
\hline Sample proportion & 0.0490 & 0.0826 & 0.104 & 0.119 & 0.150 \\
\hline LPM & 0.001 & 0.003 & 0.004 & 0.001 & 0.009 \\
\hline TSLS & $(0.004)$ & $(0.005)$ & $(0.006)$ & $(0.007)$ & $(0.007)$ \\
\hline Observations & 0.005 & 0.001 & 0.011 & -0.002 & 0.004 \\
\hline Women & $(0.005)$ & $(0.007)$ & $(0.007)$ & $(0.011)$ & $(0.010)$ \\
\hline Sample proportion & 0.0360 & 0.0756 & 0.0804 & 0.0768 & 0.0801 \\
\hline LPM & -0.002 & $0.010 *$ & -0.003 & -0.003 & -0.000 \\
\hline TSLS & $(0.003)$ & $(0.006)$ & $(0.006)$ & $(0.007)$ & $(0.005)$ \\
\hline Observations & -0.002 & 0.008 & 0.001 & 0.001 & 0.004 \\
\hline Notes: All & $(0.003)$ & $(0.008)$ & $(0.008)$ & $(0.006)$ & $(0.009)$ \\
\hline
\end{tabular}

Notes: All models control for demographics. LPM models control for school-leaving state and year fixed effects. TSLS models control for expected school-leaving state and year fixed effects. NLSY79 sample weights applied. Standard errors reported in parentheses and clustered around the school-leaving state (expected school-leaving state) in LPM (TSLS) models. ${ }^{*} \mathrm{p}<.10 .{ }^{* *} \mathrm{p}<.05$. ${ }^{* * *} \mathrm{p}<.01$. 


\section{Conclusion}

As discussed in Section 2, the school-leaving unemployment rate could impact the self-employment through several pathways. However, our results, drawn from the standard dataset to study the persistent career effects of leaving school in an economic downturn, suggest the net impact is zero. The findings contrast with the finding of $\mathrm{Yu}$ et al. (2014) who conclude, using a sample of college graduates from one university, that graduating in downturns decreases the likelihood of starting a business for up to 11 years. Our findings are important for understanding the determinants of self-employment.

\section{Acknowledgements}

We are grateful to Douglas Webber for valuable comments. 


\section{References}

Altonji, J. G., Kahn, L. B., \& Speer, J. D. (2014). Cashier or consultant? entry labor market conditions, field of study, and career success.

(NBER Working Paper No. 20531)

Evans, D. S., \& Leighton, L. S. (1989). Some empirical aspects of entrepreneurship. The American Economic Review, 519-535.

Fairlie, R. W. (2013). Entrepreneurship, economic conditions, and the great recession. Journal of Economics \&3 Management Strategy, 22(2), 207231.

Genda, Y., Kondo, A., \& Ohta, S. (2010). Long-term effects of a recession at labor market entry in japan and the united states. Journal of Human Resources, 45(1), 157-196.

Haltiwanger, J., Jarmin, R. S., \& Miranda, J. (2013). Who creates jobs? small versus large versus young. Review of Economics and Statistics, 95(2), $347-361$.

Hershbein, B. J. (2012). Graduating high school in a recession: Work, education, and home production. The BE journal of economic analysis $\mathcal{E}^{6}$ policy, 12(1).

Hipple, S. F. (2010). Self-employment in the united states. Monthly Labor Review, 133(9), 17-32.

Kahn, L. B. (2010). The long-term labor market consequences of graduating from college in a bad economy. Labour Economics, 17(2), 303-316.

Kondo, A. (2007). Does the first job really matter? state dependency in employment status in japan. Journal of the Japanese and International Economies, 21(3), 379-402.

Maclean, J. C. (2014). Does leaving school in an economic downturn impact access to employer-sponsored health insurance? IZA Journal of Labor Policy, 3(1), 1-27.

Oreopoulos, P., Wachter, T. von, \& Heisz, A. (2012). The short-and long-term career effects of graduating in a recession. American Economic Journal: Applied Economics, 4(1), 1-29.

Rampini, A. A. (2004). Entrepreneurial activity, risk, and the business cycle. Journal of Monetary Economics, 51(3), 555-573.

Yu, L., Orazem, P. F., \& Jolly, R. W. (2014). Entrepreneurship over the business cycle. Economics Letters, 122(2), 105-110. 